\title{
Tectonic pulse registered between 2013 and 2015 on the eastern margin of the Bohemian Massif
}

\author{
Miloš BRIESTENSKÝ ${ }^{1, *}$, Josef STEMBERK ${ }^{1}$, Juraj LITTVA ${ }^{2,3}$ and Rastislav VOJTKO ${ }^{3}$ \\ 1 Czech Academy of Sciences, Institute of Rock Structure and Mechanics, V Holešovičkách 94/41, 18209 Prague, Czech \\ Republic \\ 2 Slovak Caves Administration, State Nature Conservancy of the Slovak Republic, Hodžova 11, 03101 Liptovský Mikuláš, \\ Slovakia \\ 3 Comenius University, Department of Geology and Palaeontology, Faculty of Natural Sciences, Mlynská dolina, Ilkovičova \\ ulica č. 6,84215 , Bratislava, Slovakia
}

Briestenský, M., Stemberk, J., Littva, J., Vojtko, R., 2021. Tectonic pulse registered between 2013 and 2015 on the eastern margin of the Bohemian Massif. Geological Quarterly, 65: 14, doi: 10.7306/gq.1582

\begin{abstract}
A significant period of increased tectonics was monitored between 2013 and 2015 on the eastern margin of the Bohemian Massif along ten faults. Nine of them showed a uniform scheme: dextral strike-slip along generally NW-SE striking faults, sinistral strike-slip along generally NE-SW striking faults and uprising of the southern blocks. The distinguished fault displacements displayed an NNW-SSE striking compressional component of the stress field during this remarkable tectonic episode.
\end{abstract}

Key words: tectonic pulse, Bohemian Massif, compression, faults.

INTRODUCTION

An understanding of the active tectonics of regional tectonic structures requires many years of monitoring as well as a large amount of equipment. A local extensometric network was established on the eastern margin of the Bohemian Massif to reflect recent upper crustal deformation changes. Ten TM71 optical-mechanical gauges have been recording three-dimensional displacements in this area. The first gauges were installed in the Skalka Gallery in 1997, and several were subsequently installed in the Pustožlebská zazděná Cave in 2003, in the Na Turoldu Cave in 2008, in the Mladeč Caves in 2008, and in the 13C Cave in 2011. This type of monitoring is ongoing at more than 150 sites throughout Europe, and helps us to compare the results and define simultaneous activity affecting the whole of the European plate (Briestenský et al. 2015, 2018). This paper presents data concerning the orientation and character of the stress field created during the significant tectonic pulse observed on the eastern margin of the Bohemian Massif between 2013 and 2015. The results reveal the character of the tectonic pulses, which may also be different from the long-term observations. Furthermore, the paper highlights the importance of long-term tectonic monitoring.

\footnotetext{
* Corresponding author, e-mail: briestensky@irsm.cas.cz
} Received: November 20, 2020; accepted: January 14, 2021; first published online: March 23, 2021

\section{GEOLOGICAL SETTING}

The Bohemian Massif represents a result of Variscan Orogeny. It was affected by Alpine Orogeny and is separated from the Western Carpathians by the Carpathian Foredeep. The foredeep is controlled by many active fault zones, such as the Haná Fault Zone or the Diendorf-Čebín Fault Zone (Fig. 1). The latter creates a SW-NE to SSW-NNE-striking zone known as the Diendorf Fault in the south and the Boskovice Furrow in the north (Fig. 1). Both structures were initiated as ductile shear zones with a sinistral strike-slip mechanism in the Early Permian (e.g., McCann, 2008). The Permian infill of the Boskovice Furrow half-graben was uplifted above the Cretaceous rocks of the Cretaceous basin during Alpine tectonics (e.g., McCann, 2008). The Haná Fault Zone, which is incorporated into the so-called Nysa-Morava Zone, includes horst-and-graben structures, deep linear sedimentary basins, Pliocene to Pleistocene alkali basic volcanism, and recent $\mathrm{CO}_{2}$ fluxes. Active tectonics are accompanied by low magnitude seismicity (Špaček et al., 2015).

\section{METHODOLOGY - ACTIVE FAULT MONITORING}

Fault displacements are monitored by specially designed extensometric gauges, which help measure 3D deformations and block rotations in two planes perpendicular to each other. The long-term durability of these instruments has been verified e.g. at the Parohy site (Fig. 2) in the high mountains of the Western Carpathians (Briestenský et al., 2011). The site has 


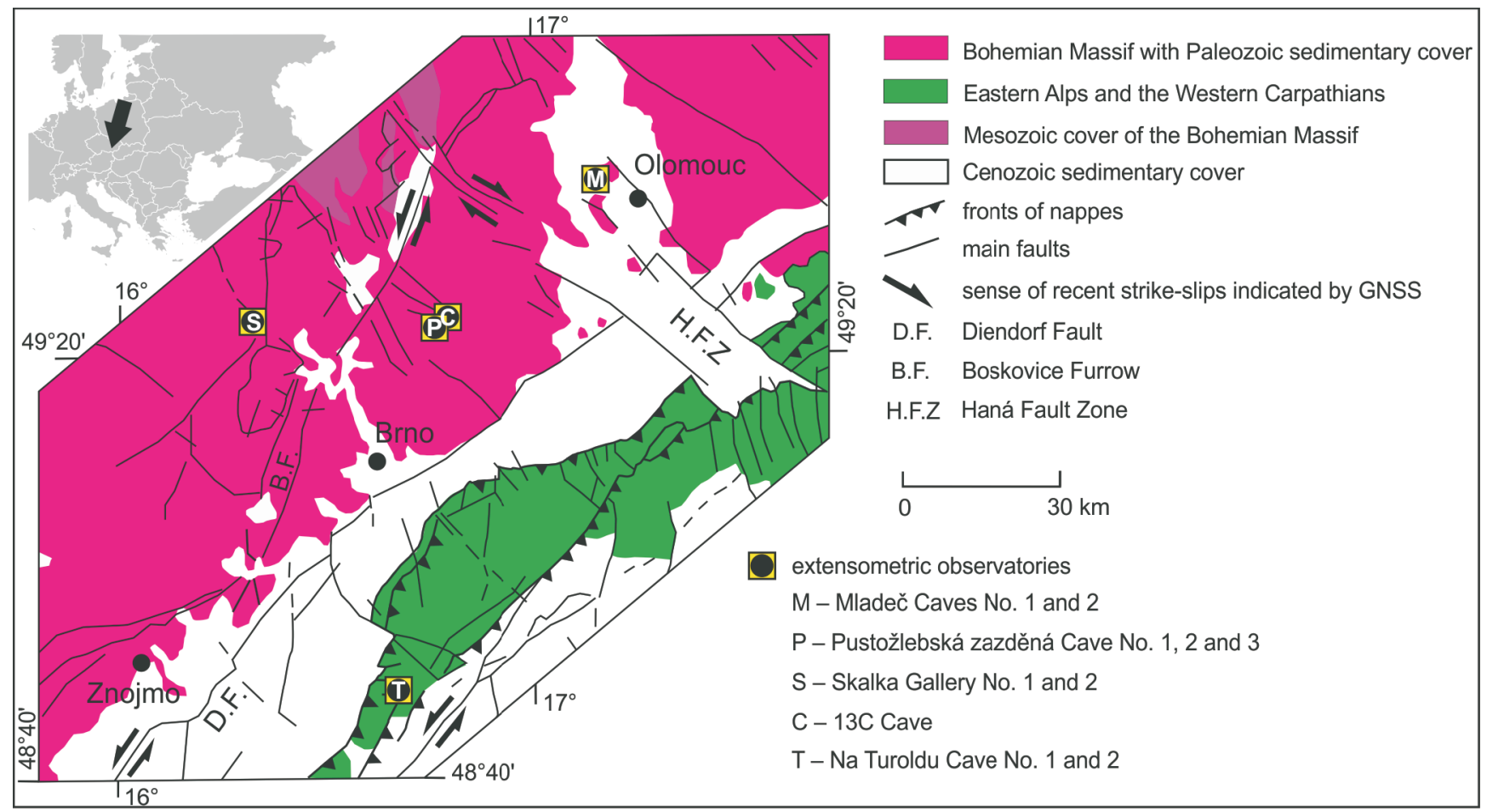

Fig. 1. Location of ten extensometric observatories on the eastern Bohemian Massif margin and the Western Carpathians front (adopted after Lenhardt et al., 2007)

The grey map in the upper-left corner shows the position of the study area in Europe

been monitored without any maintenance or reconstruction since 1973. Only a gauge without any electrical components such as a TM71 extensometer is able to survive such conditions. Most of the optical-mechanical gauges making up the extensometric network EU-TecNet (www.tecnet.cz) are installed under the surface, mostly in caves, which decreases the seasonal temperature effects that usually affect the received results (Briestenský el al., 2010a). The accuracy of the measured fault displacements is greater than $10 \mu \mathrm{m}$ per year. Recently, the methods and their detailed application were de- scribed in detail by Košták (2006), Košták et al. (2007, 2011), Gosar et al. (2009), Šebela et al. (2009), Stemberk et al. (2010, 2015), Briestenský et al. (2010, 2015, 2014a, 2014b), Klimeš et al. (2012), Marty et al. (2013), Rowberry et al. (2016) etc.

Due to fact that the results are usually presented in Cartesian coordinates, we have transformed the sense of the significant displacement into a 3D vector (Table 1), which are firstly defined by two spherical values - plunge and azimuth (Briestenský et al., 2018). Subsequently, the data were plotted on the lower hemisphere of the Equal-area stereonet using the

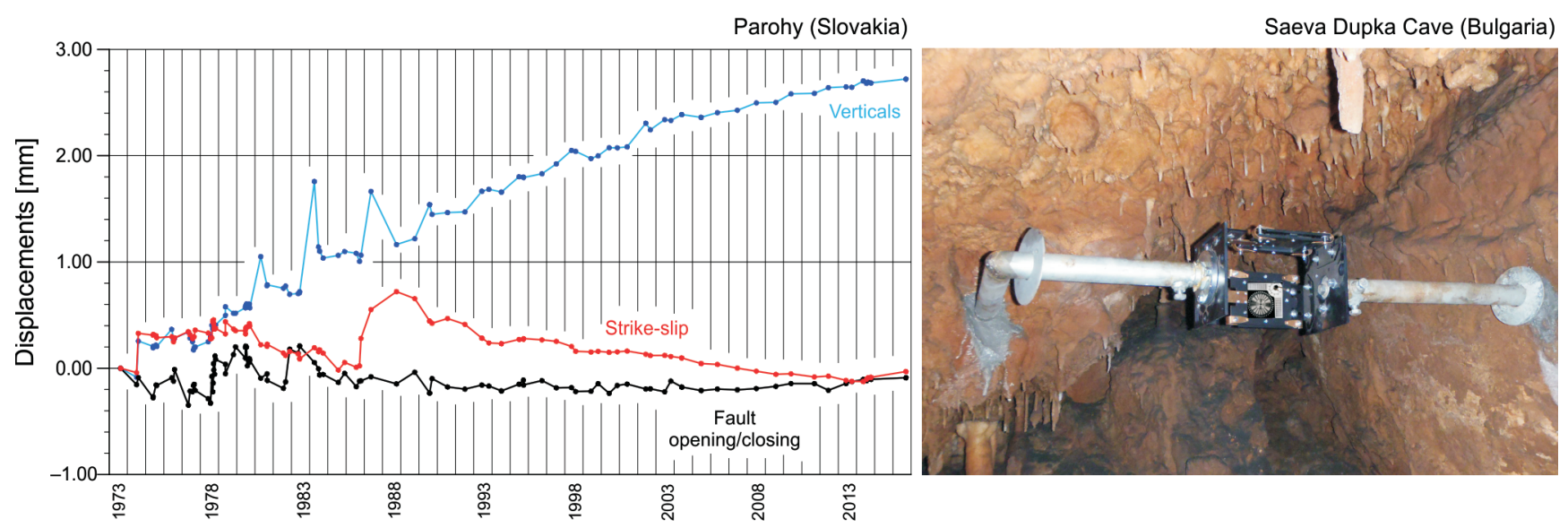

Fig. 2. Results of very long-term monitoring in the high mountains of the Western Carpathians at the Parohy site (Slovakia)

The TM71 extensometric gauge was installed in 1973 and has displayed slow creep movements in the scarp of a large Parohy slope deformation (Briestenský et al., 2010). The graph shows separate displacement components of the 3D space. The right picture shows the common installation of the TM71 instrument in the Saeva Dupka Cave (Bulgaria). The instrument is fixed in two opposite blocks, separated by the monitored fault 
Sense of significant fault displacements monitored on the eastern Bohemian Massif margin during the noticeable period between 2013 and 2015, data were used for stereographic projection and the compressional component of the recent stress field computation

\begin{tabular}{|c|c|c|c|c|}
\hline $\begin{array}{l}\text { Site } \\
\text { No. }\end{array}$ & Site Name & $\begin{array}{l}\text { Fault dip } \\
\text { direction } \\
\text { dip }^{\circ}\end{array}$ & Sense of significant fault displacements during 2013/2015 period & azimuth $^{\circ} \rightarrow$ plunge $^{\circ}$ \\
\hline 1. & Mladeč Caves No. 1 & $232^{\circ} \rightarrow 81^{\circ}$ & oblique (0.023 dextral, $0.003 \mathrm{~mm}$ NE block subsidence, $0.001 \mathrm{~mm}$ opening) / 2014 & $145^{\circ} \rightarrow 15^{\circ}$ \\
\hline 2. & Mladeč Caves No. 2 & $330^{\circ} \rightarrow 60^{\circ}$ & oblique ( $0.003 \mathrm{~mm}$ sinistral, $0.002 \mathrm{~mm}$ closing, $0.001 \mathrm{~mm}$ NW block subsidence) / 2013 & $214^{\circ} \rightarrow 0^{\circ}$ \\
\hline \multirow[t]{2}{*}{3.} & \multirow[t]{2}{*}{ 13C Cave } & \multirow[t]{2}{*}{$280^{\circ} \rightarrow 89^{\circ}$} & sinistral $(0.05 \mathrm{~mm}) / 2013$ & $197^{\circ} \rightarrow 2^{\circ}$ \\
\hline & & & normal (0.042 mm W block subsidence) / 2014 & $100^{\circ} \rightarrow 85^{\circ}$ \\
\hline 4. & Pustožlebská zazděná Cave No. & $220^{\circ} \rightarrow 80^{\circ}$ & oblique ( $0.703 \mathrm{~mm}$ dextral, $0.314 \mathrm{~mm}$ SW block subsindence, $0.174 \mathrm{~mm}$ opening) / 2013 & $291^{\circ} \rightarrow 24^{\circ}$ \\
\hline 5. & Pustožlebská zazděná Cave No. & $310^{\circ} \rightarrow 80^{\circ}$ & oblique ( $0.05 \mathrm{~mm}$ sinistral, $0.024 \mathrm{~mm}$ NW block subsidence, 0.001 closing) $/ 2014$ & $049^{\circ} \rightarrow 34^{\circ}$ \\
\hline 6. & Pustožlebská zazděná Cave No. & $190^{\circ} \rightarrow 89^{\circ}$ & oblique ( $0.127 \mathrm{~mm}$ dextral, $0.021 \mathrm{~mm}$ NE block subsidence, $0.004 \mathrm{~mm}$ opening) / 2014 & $279^{\circ} \rightarrow 14^{\circ}$ \\
\hline 7. & Skalka Gallery No. 334 & $018^{\circ} \rightarrow 60^{\circ}$ & oblique (0.862 mm NE block subsidence, $0.659 \mathrm{~mm}$ opening, $0.36 \mathrm{~mm}$ dextral) / 2014 & $126^{\circ} \rightarrow 76^{\circ}$ \\
\hline 8. & Skalka Gallery No. 410 & $244^{\circ} \rightarrow 69^{\circ}$ & none & none \\
\hline 9. & Na Turoldu Cave No. 1 & $086^{\circ} \rightarrow 76^{\circ}$ & oblique ( $0.026 \mathrm{~mm}$ E block subsidence, $0.003 \mathrm{~mm}$ dextral) / 2013 & $356^{\circ} \rightarrow 85^{\circ}$ \\
\hline 10. & Na Turoldu Cave No. 2 & $216^{\circ} \rightarrow 48^{\circ}$ & oblique (0.195 mm dextral, $0.126 \mathrm{~mm}$ closing, $0.028 \mathrm{~mm}$ NW block subsidence) / 2014-2015 & $339^{\circ} \rightarrow 9^{\circ}$ \\
\hline
\end{tabular}

Stereo32 software (Röller and Trepmann, 2003) as described in Briestenský et al. (2018). They were further processed using Win-Tensor software (Delvaux and Sprener, 2003). If the orientation of the significant displacement vector fell outside the corresponding planes, its orientation was adjusted to the closest possible fit onto the plane, in accordance with Win-Tensor's suggestions. The Improved Right Dihedron method based on the original method of Angelier and Melcher (1977) was subsequently used to separate the data and to estimate the maximum horizontal stress ( $\left.\mathrm{S}_{\text {HMAX }}\right)$ and mean stress axes $\left(\sigma_{1}, \sigma_{2}\right.$, and $\left.\sigma_{3}\right)$. Given the limited amount of data and the aim to provide only a rough estimate of the reduced tensor, the data were not further processed using the tensor Rotational Optimization method.

\section{RESULTS}

Fault displacements on the eastern margin of the Bohemian Massif do not generally display creep movements with trends, but they are manifested in so-called tectonic pulses (Figs. 3 and 4). The pulses were previously described by Stemberk et al. (2010) as a distinguished manner of the active tectonics of the Bohemian Massif.

Our results show the most significant pulse observed in 2013-2015 on margin of the eastern Bohemian Massif. The pulse showed nearly simultaneous displacements with significant strike-slip along nine of the monitored faults (Fig. 3). The strike-slip represents a displacement component that is not assumed to be caused by gravitational processes or hydrogeological factors.

During the tectonic pulse, the strike-slip displacement component was a prevalent mode of displacement in the majority of the monitored faults; although dip-slip was also occasionally present (Table 1 and Fig. 5). The NW-SE-striking faults had a dextral sense of strike-slip displacement, while the NE-SW to ENE-WSW-striking faults had a sinistral sense. The sinistral sense is in discrepancy with the defined dextral strike-slip along the Diendorf-Čebín Fault Zone (Hausmann et al., 2010; Brückl et al., 2010). On the other hand, our observation is in good conformity with the results from the Driny Cave (the Central Western Carpathians), located to the east in the Malé Karpaty Mts. (Slovakia). Here, the fault displacement monitoring displays a sinistral strike-slip along NNE-SSW striking faults, a dextral strike-slip along NW-SE striking faults, and an NNW-SSE oriented compressional component of the stress field (Briestenský et al., 2010).

Of the ten significant displacements vectors, two were separated and excluded from the further analysis during the software separation of the data in Win-Tensor. These excluded vectors were problematic in several ways. The first of the excluded vectors was from the measurements taken from in the 13C Cave, where two significant displacement senses were found. The excluded vector represents a normal movement, which almost completely rebounded within half a year (Fig. 3). A similar rebound, albeit in a shorter timeframe, was also observed in the second of the excluded displacement vectors measured at Skalka Gallery (Fig. 4). Moreover, the measurement came from the only surface locality of this study and the displacement vector was one of the three vectors that had to be adjusted onto the fault plane.

The calculated data of estimated stress orientation from the remaining displacement vectors further supports the notion of the strike-slip regime with NNW-SSE-striking maximum compression in the studied area in the period between 2013 and 2015 (Fig. 5). Using the Improved Right Dihedron method, the stress orientation was determined as following: azimuth $345.2 \pm 5.9$ for the $S_{\text {HMAX }}$ and the azimuth/plunge 341/29 ( \pm 14.6$)$ for $\sigma_{1}, 193 / 56( \pm 16.9)$ for $\sigma_{2}$, and $78 / 15( \pm 13.3)$ for $\sigma_{3}$ (with strike-slip tectonic regime). The counting deviation was $24.4 \pm 4$. These results show that fault-slip analysis of the movements obtained from 3-D monitoring of active faults may be used to provide a rough estimate of the principal stress orientation (see also Stemberk et al., 2019a). Furthermore, we speculate that given a sufficient amount of data these methods may be used to reliably determine the orientation of the stress tensor of recent crustal stresses. Our results are in good conformity with GPS studies (Pospíšil et al., 2012, 2017), which showed a dextral strike-slip along NW-SE-striking faults (Nectava-Konice Fault) and a sinistral strike-slip along NE-SW-striking faults (Boskovice Furrow, Diendorf Fault, Bulhary Fault) in the eastern part of the Bohemian Massif (Fig. 1). Moreover, computed stress-field orientation is in good conformity with the results from neighbouring areas: (1) NW-SE oriented horizontal compression in the Outer Western Carpathians (Jarosiński, 1998, 

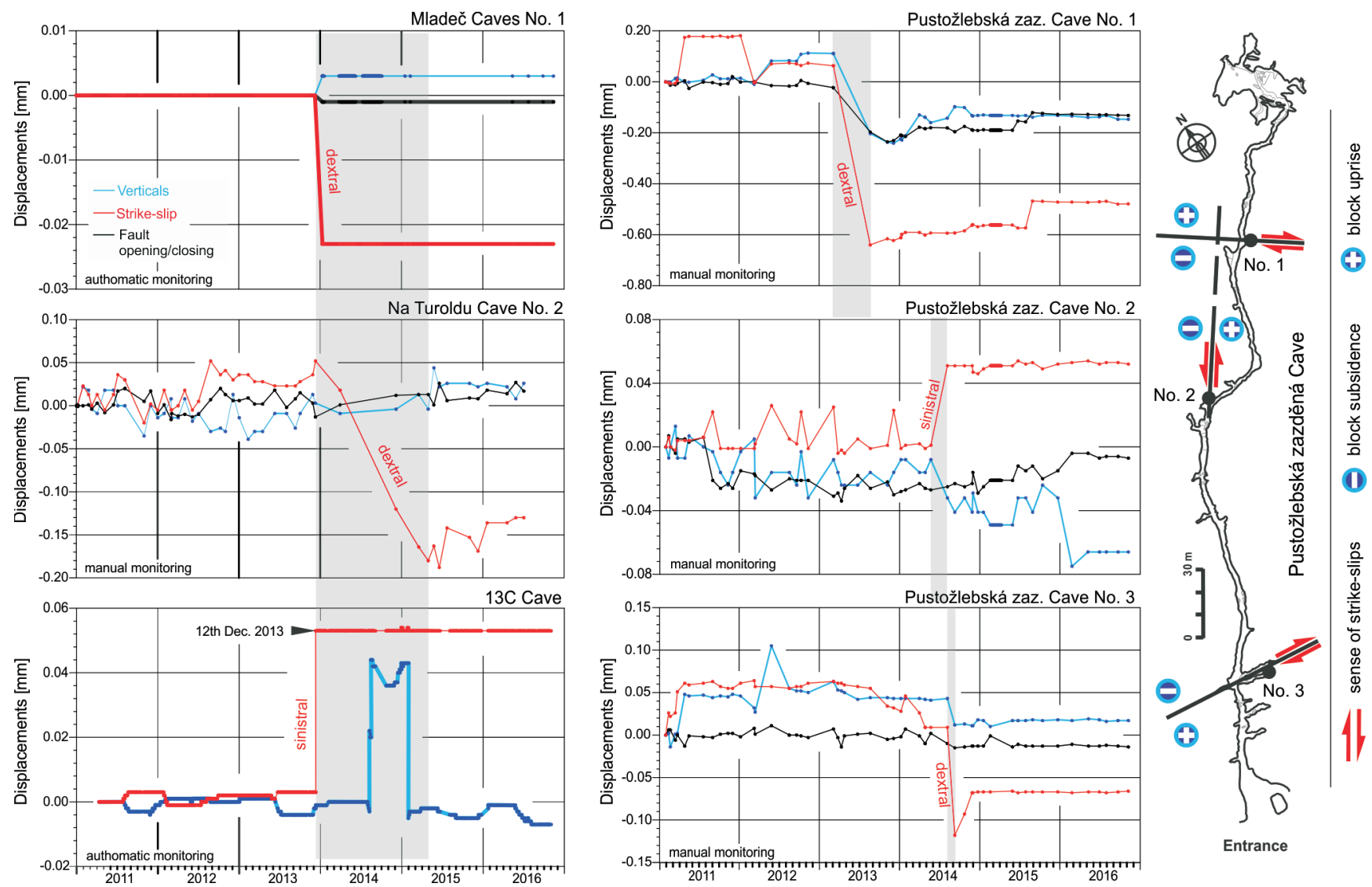

Fig. 3. The fault displacements recorded on the eastern margin of the Bohemian Massif

Increased faulting activity began in 2013 and finished in the first half of 2015. The Pustožlebská zazděná Cave displayed gradual faulting from the centre of the massif to the edge (from the interior to the entrance). The graphs on the left show the beginning of the faulting on 12 December 2013, when strike-slips were activated in the 13C Cave and simultaneously in the Mladeč Caves. Both sites are $103 \mathrm{~km}$ apart (striking $15.26^{\circ}$ )

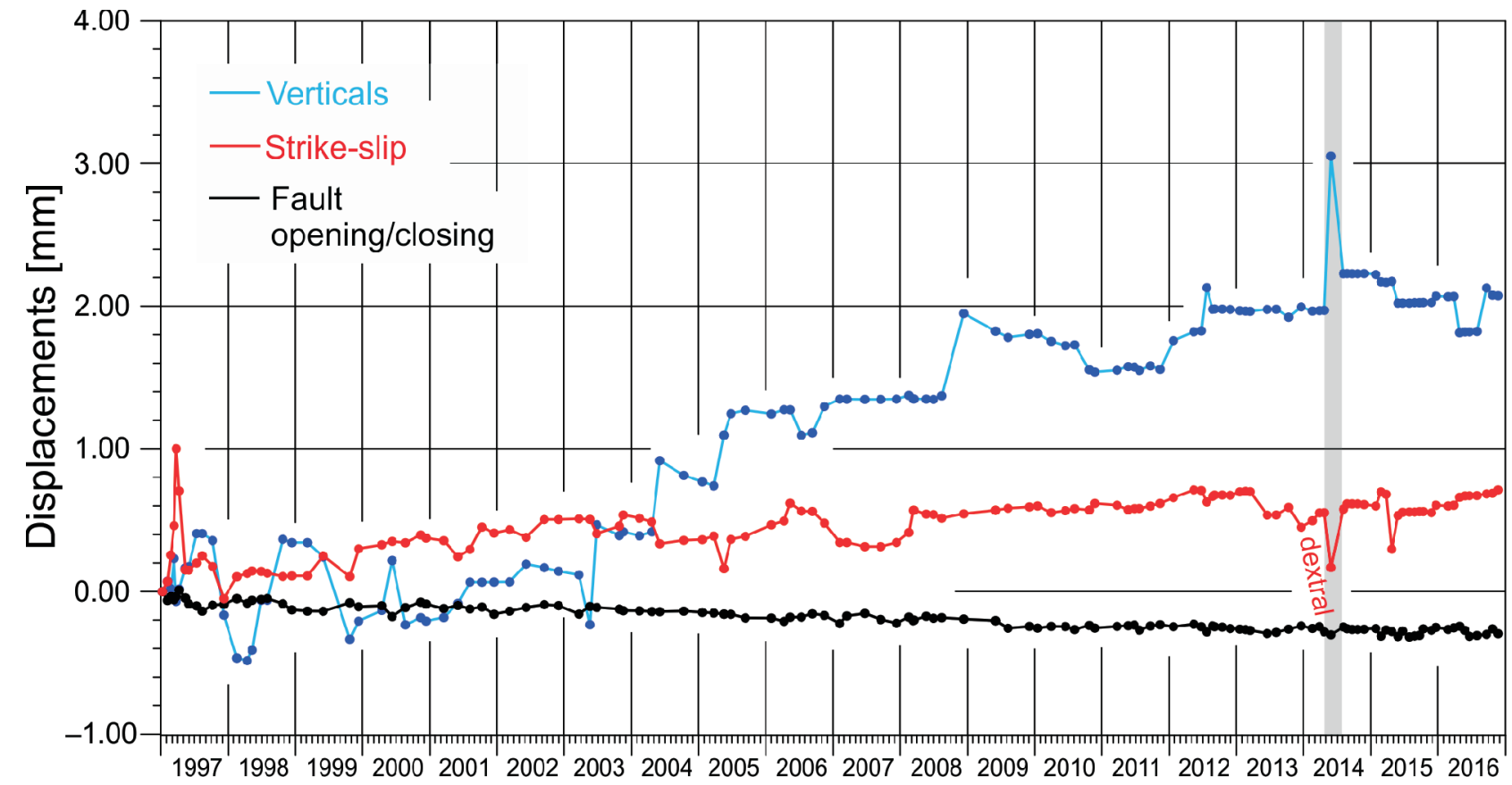

Fig. 4. Displacements registered across the monitored fault in the Skalka Gallery (site No. 334, see Table 1) 


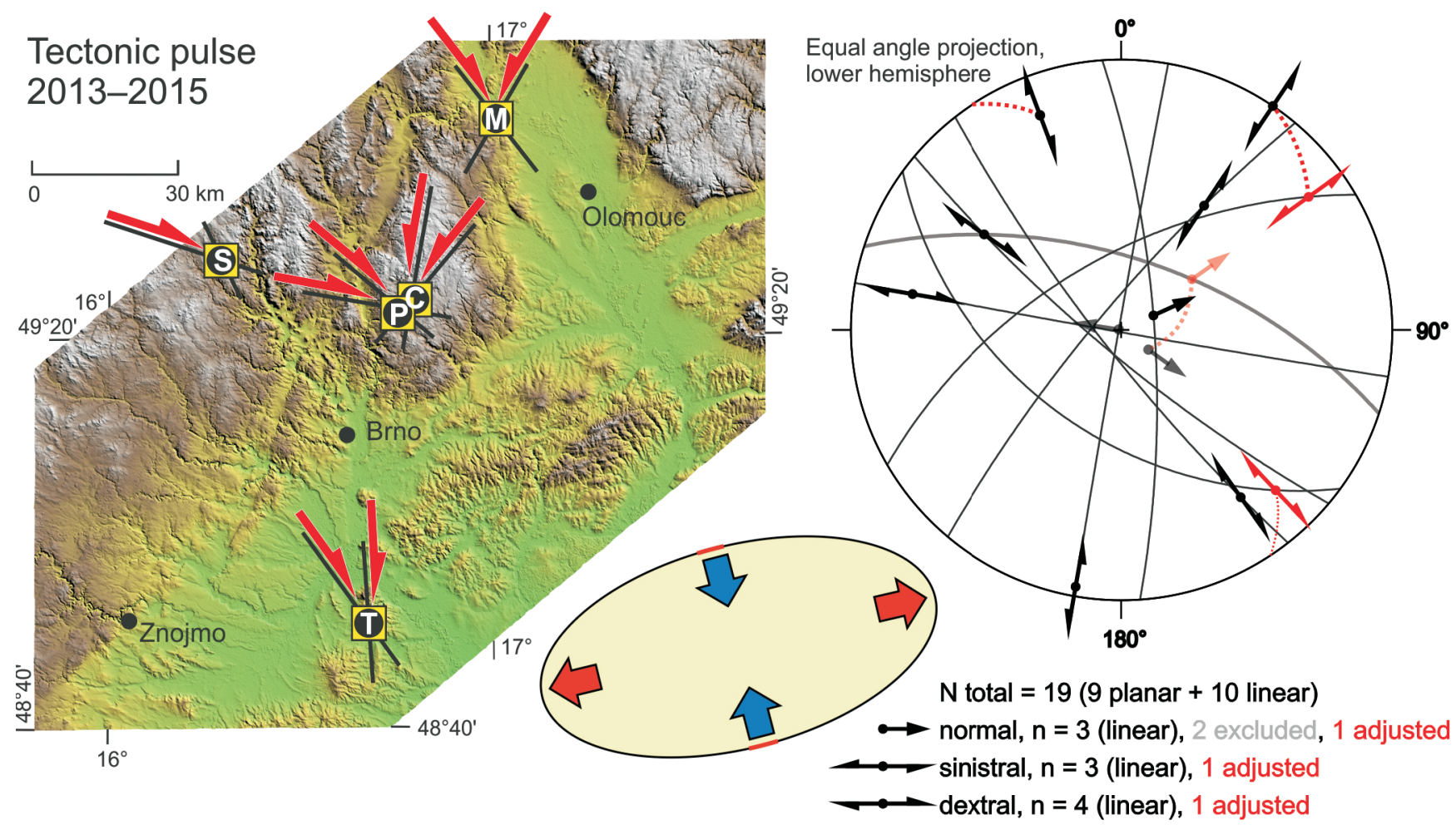

Fig. 5. Sense of strike-slips monitored along the faults on the eastern margin of the Bohemian Massif during the significant tectonic pulse between 2013 and 2015

The stereographic projection on the right shows the fault planes (black great circles) and displacement vectors (projected as points). Adjustment of the lineation in the WinTensor software is indicated by dashed lines and red colour and excluded data are indicated by the grey colour. Computed mean stress axes are in the centre
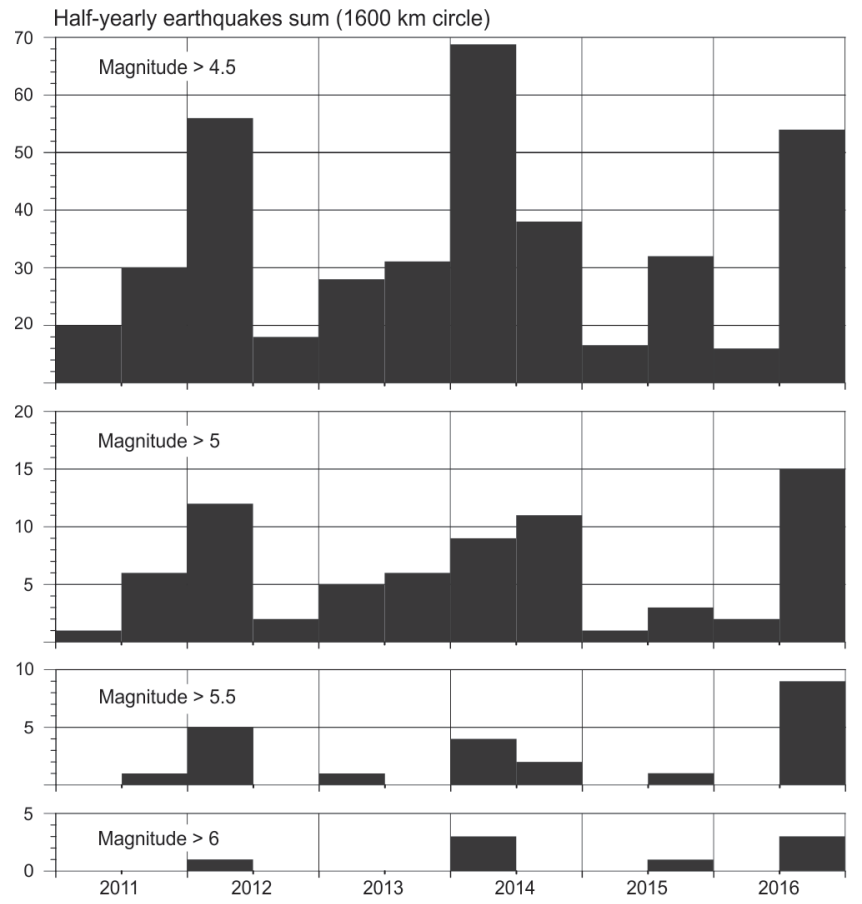
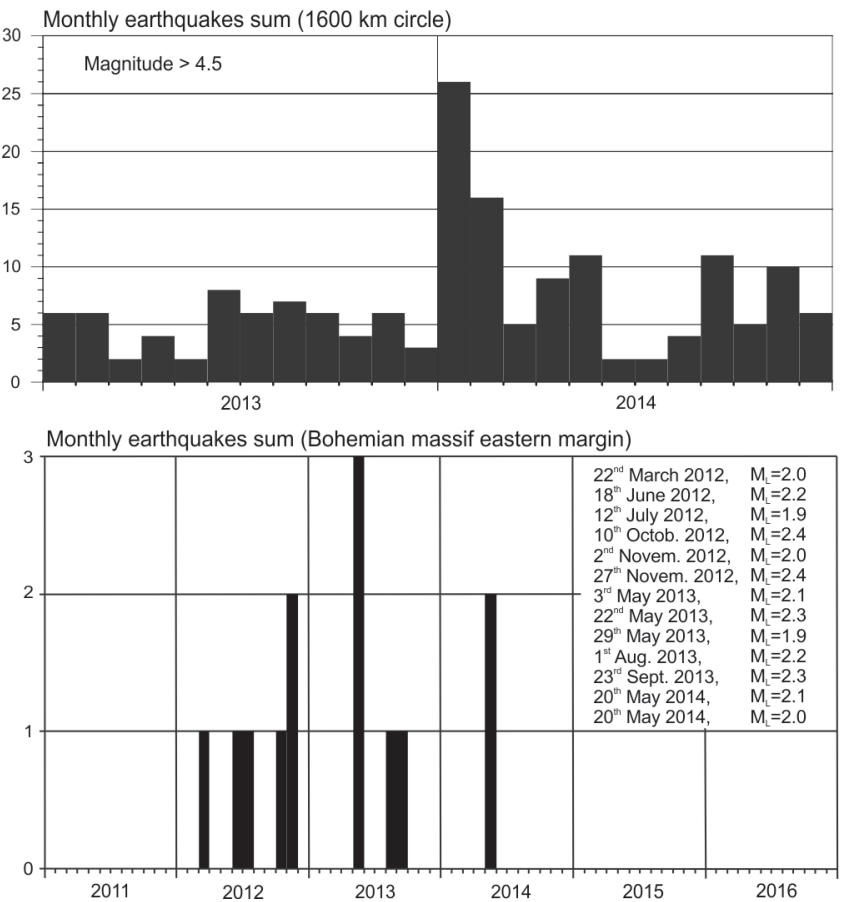

Fig. 6. Distribution of half-yearly earthquakes between 2011 and 2016 and monthly distribution between 2013 and 2014 in the circle with a radius of $1600 \mathrm{~km}$ from the $13 \mathrm{C}$ Cave (Centre: $49.40 \mathrm{~N} ; 16.77 \mathrm{E}$ )

The first two months of 2014 show increased earthquake activity all over Europe (source: https://earthquake.usgs.gov/earthquakes), which is in good conformity with registered faulting activity on the eastern Bohemian Massif margin. The lower-right graph shows the time distribution and a list of local earthquakes observed on the eastern margin of the Bohemian Massif (source: www.emsc-csem.org) 
2005; Stemberk et al., 2016), (2) NNW-SSE (Haviŕ, 2004) and WNW-ESE/NW-SE (Stemberk et al., 2019b) in the Jeseníky region, (3) the Czech part of the Upper Silesian basin (Peška, 1992), (4) NNW-SSE in the central Western Carpathians (Briestenský et al., 2010b), (5) NW-SE in the Nisa-Morava Zone (Špaček et al., 2015).

The significant period between 2013 and 2015 led us to search for correlations with seismicity. Here, the faulting began in the first half of 2013 in at the Pustožlebská zazděná Cave No. 1 (Fig. 3) and during this period, three local earthquakes were monitored in the area of the eastern Bohemian margin. Moreover, noticeable mutual faulting began in December 2013, which was observed on the southernmost site of the Na Turoldu Cave and in the northernmost Mladeč Caves (distance = $103 \mathrm{~km}$, Fig. 3). The automatic data collection in the 13C Cave revealed the start of the late autumn fault activation on 12 December 2013.

The strike-slip displacements also continued until the first half of 2015 in the Na Turoldu Cave (Site No. 2; Fig. 2). Moreover, the start of the faulting at the end of 2013 was followed by increased seismic activity on the European Platform (Fig. 6), regarding events in a circle with a radius of $1600 \mathrm{~km}$ (source: https://earthquake.usgs.gov/earthquakes). This fact shows that the faulting was not evoked by increased seismicity, but both phenomena displayed accelerated tectonics at the end of 2013 and the beginning of 2014. Figure 6 shows monthly earthquake sums of 2013 and 2014 with increased seismicity in January 2014.

\section{DISCUSSION}

Regarding our stress-field results from 2013 to 2015, observed on the eastern margin of the Bohemian Massif, and the above-mentioned reports from the other Carpathian foredeep sites, a significant pattern may be noticed. The reported stress-field orientations are generally defined as perpendicular to the Carpathian Arc (Jarosiński, 2005; Špaček et al., 2015; Hók et al., 2016), referred to as the continual recent ALCAPA push (Jarosinski, 2005). Therefore, NNW-SSW striking $S_{H \max }$, during the presented 2013-2015 period, slightly deviates from the general scheme. A study from the Upper Silesian Coal Basin (Mendecki et al., 2020) reveals more significant discrepancy. The results of seismic moment tensor inversion in the area of the Bytom Syncline show the compression acting in an NE-SW direction. This deviates from the expected general
NW-SE direction. Moreover, Stemberk et al. (2019b) described two switching compressional stress/strain states - WNW-ESE to NW-SE compression and the NNE-SSW compression in the Dědičná štola Gallery in the Rychlebské hory Mts. during the period between 2014 and 2017. It may be speculated that these deviations are produced by the episodical clockwise or counterclockwise rotation of the ALCAPA microplate. This phenomenon was described for the previous development of the unit. For example, after the early Miocene tectonic phase, the Western Carpathian push was accompanied by a counterclockwise rotation of $\sim 60^{\circ}$ with respect to the European Platform (Márton et al., 1999).

\section{CONCLUSIONS}

Our extensometric monitoring showed a significant increase in tectonic activity in the period between 2013 and 2015 on the eastern margin of the Bohemian Massif. During this time, fault micro-displacements allude to the following uniform scheme: dextral strike-slip along generally NW-SE striking faults, sinistral strike-slip along generally NE-SW striking faults and uplift of the southern blocks. These eminent microdisplacements were utilized in the software fault-slip analyses to determine the orientation of the principal stresses that generated them - an approach that to our knowledge has only been tried in a few other studies in this particular field. The estimate of the stress tensor calculated by the Win-Tensor program shows a strike-slip stress-field with the main compression axis having an NNW-SSE orientation. Increased mutual microdisplacements occurred in December 2013 in the whole space, and following increased seismic activity in Europe in January 2014, support the importance of the observed displacements on the nine monitored fault structures. This fact provides a correlation between these two phenomena.

Acknowledgement. We thank D. Coufalová and J. Kolařík for their help with monitoring and assistance during the fieldwork. The research was supported by the long-term conceptual development research organization RVO: 67985891; APVV projects No. APVV-0099-11 and No. APVV-0315-12 and the infrastructural projects CzechGeo (LM2015079) and CzechGeo/EPOS-Sci CZ.02.1.01/0.0/0.0/16_013/0001800. The scientific results were obtained using Win-Tensor, a software developed by Dr. D. Delvaux, Royal Museum for Central Africa, Tervuren, Belgium.

\section{REFERENCES}

Angelier, J., 1984. Tectonic analysis of fault slip data sets. Journal of Geophysical Research, 8: 5835-5848.

Angelier, J., 1989. From orientation to magnitudes in paleostress determinations using fault slip data. Journal of Structural Geology, 11: 37-50.

Angelier, J., 1990. Inversion of field data in fault tectonics to obtain the regional stress - III. A new rapid direct inversion method by analytical means. Geophysical Journal Interior, 103: 363-376.

Angelier, J., 1994. Fault slip analysis and Paleostress reconstruction. In: Continental Deformation (ed. P. L. Hancock): 53-100. Pergamon Press, Bristol.

Angelier, J., Taranola, A., Valette, W., Manousis, S., 1982. Inversion of field data in fault tectonics to obtain the regional stress I. single-phase fault populations: a new method of computing the stress tensor. Geophysical Journal International, 69 607-621.

Angelier, J., Melcher, J., 1997. Sur une method graphique de recherché des contraintes contraintes principales egalement utilisable en tectonique et en seismologie: la methode des diedres droits. Bulletin de la Société Géologique de France, 7: 1309-1318.

Briestenský, M., Košt'ák, B., Stemberk, J., Petro, L’., Vozár, J., Fojtíková, L., 2010a. Active tectonic fault microdisplacement analyses: a comparison of results from surface and underground monitoring in western Slovakia. Acta Geodynamica et Geomaterialia, 7: 387-397.

Briestenský, M., Stemberk, J., Michalík, J., Bella, P., Rowberry, M.D., 2010b. The use of a karstic cave system in a study of ac- 
tive tectonics: fault movements recorded at Driny Cave, Malé Karpaty Mts. (Slovakia). Journal of Cave and Karst Studies, 73: 114-123.

Briestenský, M., Košt’ák, B., Stemberk, J., Vozár, J., 2011. Long-term slope deformation monitoring in the high mountains of the Western Carpathians. Acta Geodynamica et Geomaterialia, 8: 403-412.

Briestenský, M., Stemberk, J., Rowberry, M.D., 2014a. The use of damaged speleothems and in situ fault displacement monitoring to characterise active tectonic structures: an example from Západní Cave, Czech Republic. Acta Carsologica, 43: 129-138.

Briestenský, M., Thinová, L., Praksová, R., Stemberk, J., Rowberry, M.D., Knejflová, Z., 2014b. Radon, carbon dioxide, and fault displacements in central Europe related to the Tôhoku Earthquake. Radiation Protection Dosimetry, 160: 78-82.

Briestenský, M., Rowberry, M.D., Stemberk, J., Stefanov, P., Vozár, J., Šebela, S., Petro, L'., Bella, P., Gaal, L'., Ormukov, Ch., 2015. Evidence of a plate-wide tectonic pressure pulse provided by extensometric monitoring in the Balkan Mountains (Bulgaria). Geologica Carpathica, 66: 427-438.

Briestenský, M., Hochmuth, Z., Littva, Hók, J., Dobrovič, R., Stemberk, J., Petro, L'., Bella, P., 2018. Present-day stress orientation and tectonic pulses registered in the caves of the Slovenský kras Mts. (South-Eastern Slovakia). Acta Geodynamica et Goematerialia, 15: 93-103.

Brückl, E., Behm, M., Decker, K., Grad, M., Guterch, A., Keller, G.R., Thybo, H., 2010. Crustal structure and active tectonics in the Eastern Alps. Tectonics, 29, TC2011.

Delvaux, D., Sperner, B., 2003. Stress tensor inversion from fault kinematic indicators and focal mechanism data: the TENSOR program. Geological Society Special Publications, 212: 75-100.

Gosar, A., Šebela, S., Košt'ák, B., Stemberk, J., 2009. Surface versus underground measurements of active tectonic displacements detected with TM 71 extensometers in western Slovenia. Acta Carsologica, 38: 213-226.

Hausmann, H., Hoyer, S., Schurr, B., Brückl, E., Houseman, G., Stuart, G., 2010. New seismic data improve earthquake location in the Vienna Basin area, Austria. Austrian Journal of Earth Sciences, 103: 2-14.

Havír, J., 2004. Orientation of recent principal stress axes in the Jeseníky region. Acta Geodynamica et Goemoaterialia, 1: 49-57.

Hók, J., Kysel, R., Kováč, M., Moczo, P., Kristek, J., Kristeková, M., Šujan, M., 2016. A seismic source zone model for the seismic hazard assessment of Slovakia. Geologica Carpathica, 67: 273-288.

Jarosiński, M., 1998. Contemorary stress field distortion in the Polish part of the Western Outer Carpathians and their basement. Tectonophysics, 297: 91-119.

Jarosiński, M., 2005. Ongoing tectonic reactivation of the Outer Carpathians and its impact on the foreland: Results of borehole breakout measurements in Poland. Tectonophysics, 410: 189-216.

Klimeš, J., Rowberry, M.D., Blahůt, J., Briestenský, M., Hartvich, F., Košt'ák, B., Rybář, J., Stemberk, J., Štěpančíková, P., 2012. The monitoring of slow-moving landslides and assessment of stabilisation measures using an optical-mechanical crack gauge. Landslides, 9: 407-415.

Košt'ák, B., 2006. Deformation effects in rock massifs and their long-term monitoring. Quarterly Journal of Engineering Geology and Hydrogeology, 39: 249-258.

Košt'ák, B., Cacoń, S., Dobrev, N.D., Avramova-Tacheva, E., Fecker, E., Kopecký, J., Petro, L'., Schweizer, R., Nikonov, A.A., 2007. Observations of tectonic microdisplacements in Europe in relation to the Iran 1997 and Turkey 1999 earthquakes. Izvestiya Physics of the Solid Earth, 43: 503-516.

Košt'ák, B., Mrlina, J., Stemberk, J., Chán, B., 2011. Tectonic movements monitored in the Bohemian Massif. Journal of Geodynamics, 52: 34-44.

Lenhardt, W.A., Švancara, J., Melichar, P., Pazdírková, J., Havír, J., Sýkorová, Z., 2007. Seismic activity of the Al-
pine-Carpathian-Bohemian Massif region with regard to geological and potential field data. Geologica Carpathica, 58: 397-412.

Marti, X., Rowberry, M.D., Blahůt, J., 2013. A MATLAB® code for counting the moiré interference fringes recorded by the optical-mechanical crack gauge TM-71. Computers \& Geosciences, 52: 164-167.

Márton, E., Mastella, L., Tokarski, A.K., 1999. Large counterclockwise rotation of the Inner Western Carpathian Paleogene flysh Evidence from paleomagnetic investigations of the Podhale Flysh (Poland). Physics and Chemistry of the Earth, Part A: Solid Earth and Geodesy, 24: 645-649.

McCann, T., 2008. The Geology of Central Europe, 2: Mesozoic and Cenozoic. Geological Society, London.

Mendecki, J.M., Szczygiel, J., Lizurek, G., Teper, L., 2020. Mining-triggered seismicity governed by a fold hinge zone: The Upper Silesian Coal Basin, Poland. Engineering Geology, 274: 105728.

Peška, P., 1992. Stress indications in the Bohemian Massif: reinterpretation of borehole televiewer data. Studia Geographica at Godaetica, 36: 307-324.

Pospíšil, L., Roštínský, P., Švábenský, O., Weigel, J., Witiska, M., 2012. Active tectonics in the eastern margin of the Bohemian Massif - based on geophysical, geomorphological and GPS data. Acta Geodynamica et Geomaterialia, 9: 315-329.

Pospíšil, L., Švábenský, O., Roštínský, P., Nováková, E., Weigel, J., 2017. Geodynamic risk zone at northern part of the Boskovice Furrow. Acta Geodynamica et Geomaterialia, 14: 113-129.

Rowberry, M.D., Kriegner, D., Holy, V., Olejnik, K., Llull, M., Frontera, C., Marti, X., 2016. The instrumental resolution of a moiré extensometer in light of its recent automatization. Measurements, 91: 258-265.

Röller, K., Trepmann, C. A., 2003. Stereo32, software, Ruhr Universität, Bochum, Germany, http://www.ruhr-uni-bochum.de/ hardrock/downloads.html

Sperner, B., Müller, B., Heidbach, O., Delvaux, D., Reinecker, J., Fuchs, K., 2003. Tectonic stress in the Earth's crust: advances in the World Stress Map project. Geological Society Special Publications, 212: 101-116.

Stemberk, J., Košt'ák, B., Cacoń, S., 2010. A tectonic pressure pulse and increased geodynamic activity recorded from the long-term monitoring of faults in Europe. Tectonophysics, 487: $1-12$.

Stemberk, J., Briestenský, M., Cacoń, S., 2015. The recognition of transient compressional fault slow-slip along the northern shore of Hornsund Fjord, SW Spitsbergen, Svalbard. Polish Polar Research, 36: 109-123.

Stemberk, J., Hartvich, F., Blahút, J., Rybář, J., Krejčí, O., 2017. Tectonic strain changes affecting the development of deep seated gravitational slope deformations in the Bohemian Massif and Outer Western Carpathians. Geomorphology, 298: 3-17.

Stemberk, J., Dal Moro, G., Stemberk, J., Blahůt, J., Coubal, M., Košt’ák, B., Zambrano, M., Tondi, E., 2019a. Strain monitoring of active faults in the central Apennines (Italy) during the period 2002-2017. Tectonophysics, 750: 22-35.

Stemberk, J., Coubal, M., Stemberk, J., Štěpančíková, P., $2019 b$. Stress analysis of fault slips data recorded within the Dědičná štola gallery in the Rychlebské hory Mts., NE part of the Bohemian Massif. Acta Geodnymica et Geomaterialia, 16: 315-330.

Šebela, S., Turk, J., Mulec, J., Košt’ák, B., Stemberk, J., 2009. Statistical evaluation of the 3D monitoring of displacements of Dinaric Fault zone in Postojna Cave, Slovenia. Acta Geodynamica et Geomaterialia, 6: 163-176.

Špacek, P., Bábek, O., Štepancíková, P., Švancara, J., Pazdírková, J., Sedláček, J., 2015. The Nysa Morava Zone: an active tectonic domain with Late Cenozoic sedimentary grabens in the Western Carpathians' foreland (NE Bohemian Massif). International Journal of Earth Sciences, 104: 963-990. 